\title{
As sandálias de Plínio, o Velho
}

\author{
The sandals of Pliny the Elder
}

Thiago David Stadler*

Resumo: Neste artigo busco apresentar alguns traços que compõem uma breve biografia de Plínio, o Velho. Auxiliado pelos testemunhos de Plínio, o Jovem, construímos duas imagens que se sustentam tão somente se entendidas conjuntamente: Plínio com sandálias e Plínio sem sandálias. No primeiro caso, tem-se o astuto explorador, o cidadão que age. No segundo caso, tem-se o estudioso, o erudito que medita. É no contato destas duas imagens que apresentamos um ensaio de como construir uma figura mais apropriada de Plínio, o Velho. Figura fugidia a cada nova afirmação, mas que desvela importantes atributos de um cidadão tipicamente romano do século I.

\begin{abstract}
In this article, I aim to introduce some features that compose a brief biography of Pliny the Elder. Supported by the testimonies of Pliny the Younger, I build two images that are sustained only when comprehended together: Pliny with sandals and Pliny without sandals. In the first case, there is the sharp explorer, the citzen that acts. In the second case, there is the studious, the scholar who meditates. It is in the contact of these two images that I present an experiment of how to build a more appropriate figure of Pliny the Elder. A fugitive figure at every new assert, but that reveals important aspects of a tipical Roman citzen of the I century.
\end{abstract}

\author{
Palavras-chave: \\ Biografia; \\ Império Romano; \\ Plínio, o Velho.
}

\footnotetext{
* Doutor em História. Professor Adjunto do Colegiado de Filosofia da Universidade Estadual do Paraná campus União da Vitória. Professor Permanente do Programa de Mestrado Profissional em Filosofia (PROF-FILO). Professor Colaborador do Programa de Pós-Graduação em História da Universidade Federal do Paraná (PPGHIS). Pesquisador do Núcleo de Estudos Mediterrânicos (NEMED/UFPR).
} 


\section{Ponha o fim no princípio...}

N

o início da noite de 24 de agosto de 79, um cidadão romano de grande erudição observava uma densa fumaça que se formava sobre Pompeia, Herculano e Estábia. Tinha 56 anos. Chamava-se Caio Plínio Segundo ou, como os ventos fortes da história o tornariam conhecido, Plínio, o Velho. Cego ao perigo que se formava, vislumbrou o coroamento dos estudos que vinha desenvolvendo sobre a natureza. Tratava-se da erupção do Vesúvio. Sua capacidade de observação e curiosidade acerca do mundo natural não eram os únicos incentivos que o fizeram subir em uma embarcação e seguir até o local da erupção. Ocupava o cargo de almirante da frota de Miseno, ao norte da Bacia de Nápoles e, portanto, sua ida até Pompeia fazia parte de seu ofício. Não trazia em si germe algum de mártir da ciência, como séculos depois lhe imputaram, mas uma aguda percepção de cumprimento de seus afazeres, mesclada a uma disposição favorável ao contato com o desconhecido.

Por afazeres ou por propensão ao desconhecido, tanto faz. O fato é que as roupas de um rico integrante do grupo provincial dos equestres romanos, tecidas com raro afinco, teriam marcas da força abusiva da natureza. Enegrecidas por pó, cinzas e fogo. A noite daquele antigo presente não era escura como uma noite sem lua. Era uma obscuridade quase obscena. Pedras, que excediam à força dos homens, faziam com que Plínio e seus mui ligeiros companheiros de nau remassem com toda força por ver se da morte escapariam. Diante da calamidade vesuviana, já era possível ouvir os gritos das mulheres, o choro das crianças, os clamores dos homens. Alguns erguiam as mãos aos deuses almejando que bem rápido tudo acabasse. Outros diziam que deuses já nem sequer existiam. ${ }^{1}$ Sabe-se bem de que forma todo este mundo terminou. $O$ cortejo da morte com seu quinhão funesto agarrou o peito audaz de Plínio e tantos outros. $O$ tudo se tornou o nada. As pequenas e grandes pedras a tudo quebrou. $O$ forte fogo ardeu. As mãos portentosas da morte outros corpos ultrajaram.

Já revelada a morte adiantada de Plínio, creio que certas facetas de um Plínio ainda vivo podem compor esta narrativa. Sem anseios de uma declarada biografia, dedico

\footnotetext{
${ }^{1}$ Em uma das epístolas de Plínio, o Jovem $(6,20)$, tem-se o registro do dia 25 de agosto de 79, em que desgraças e tristezas são expostas para que Tácito pudesse compreender aquele momento: "Apenas nos sentamos [Plínio, o Jovem e sua mãe] e caiu a noite, porém não escura como uma noite sem lua, mas como uma moradia completamente fechada e sem nenhuma lâmpada acesa. Era possível ouvir os gritos das mulheres, o choro das crianças, os clamores dos homens [...], alguns chamavam aos gritos a seus pais, outros a seus filhos, outros, enfim, a seus cônjuges, e tentavam localizá-los por suas vozes. Alguns choravam sua própria desgraça, outros a de seus queridos. Estavam os que, por medo da morte, invocavam à morte mesma; os que erguiam as mãos aos deuses, e outros que diziam que esses já não existiam e interpretavam aquela noite como o fim do mundo, e não faltavam os que acrescentavam aos perigos reais outros fictícios e inventados".
} 
as futuras linhas para ensejar Plínio e seus poucos testemunhos de vida. A ele, desde tempos remotos, fora a narrativa da morte a condutora de sua própria vida. Movimento estranhamente dialético que na partida revela o desfecho. Sem contrariar esta lastimosa constatação, também oferecerei um Plínio que se ordena pelo morrer.

Nas epístolas que Plínio, o Jovem, seu sobrinho, escreveu tempos após o trágico acontecimento que matou a seu tio, foi dado certo espaço para que o inesperado e o singular aparecessem. Após falar assim, caso tenhas observado o título que pouco antes apareceu, tal inesperado e singular eu revelo, sem demoras, é um par de sandálias. Então, para continuar a leitura, nos pés terás que se focar, já que as sandálias ambos os pés de Plínio, o Velho, calçaram. Foi na epístola 6, 16 que Plínio, o Jovem, veio a revelar que, desistindo de prosseguir os estudos em virtude das espessas nuvens que se mostravam no horizonte de seu olhar, seu tio, Plínio, o Velho, calçou suas sandálias e para uma montanha se dirigiu. Com os pés descalços eram os estudos que ocupavam a sua mente inquieta. Com as sandálias em seus pés, avistou aquilo que tanto o fascinava. Após um ansioso espasmo de admiração, as mesmas sandálias o puseram a caminho do socorro de tantos viventes que enfrentavam o vociferar de um vulcão. Foi com estas mesmas sandálias que nos pés trazia que Plínio encontrou o seu próprio fim na tarde do dia 25 de agosto de 79.

Infecunda seria a tentativa de recuperar temores e destemores da vida de Plínio, o Velho, com ou sem as sandálias, sem dar espaço para as palavras que muito contribuíram para a sua imortalidade literária. Palavras moldadas com o fino traço que seu sobrinho dotado de delicadeza e destreza as fixou em algumas poucas epístolas. Ficar apenas nos testemunhos deixados pelo próprio Plínio, o Velho, quase nada se revelaria. Falou certa vez que não se deveriam buscar glórias pessoais ao escrever uma obra, mas tão somente a glória voltada ao nome de Roma (Plínio, Naturalis Historia, Praef., 16). Falou também que algumas obras públicas visivelmente serviam à melhoria pública, tais como os meios de navegação inventados por Éritras, Semíramis, Alexandre Magno, Ptolomeu Sóter, Demétrio, Ptolomeu Filadelfo, Ptolomeu Filopator e Minos (Plin., Nat. Hist., 7, 206-209). Sem falseamento, comunicou que o futuro imperador Tito fora um bom companheiro nos acampamentos militares (Plin., Nat. Hist., Praef., 3). Em um belo momento, afirmou que um estudioso verdadeiro era aquele que possuía conhecimentos úteis e os transmitia (Plin., Nat. Hist., 5, 16), mas cônscio de que não se tem explicação para tudo, ainda assim 
o melhor instrumento para a instrução seria usar a inteligência para penetrar os possíveis mistérios e dúvidas dos vários assuntos (Plin., Nat. Hist., 2, 55; 17, 29).

Então, após estarem reunidas estas breves revelações de Plínio, o Velho, todas juntas, indicam poucos traços de sua própria vivência. Vou, pois, incorporar o fino traço de Plínio, o Jovem, remetendo-se a Tácito:

Meu tio estava estacionado em Miseno como comandante da frota. Era 24 de agosto, ainda no início da noite, quando minha mãe mostrou ao meu tio a aparição de uma nuvem, com tamanho e aparência anormal. Ele havia, segundo seu costume, tomado sol, depois um banho de água fria e havia comido algo e se encontrava naquele momento ocupado com seus livros. Pediu então que the alcançasse suas sandálias e subiu até um local de onde podia ver melhor aquele prodígio (Plínio, o Jovem, Epistulae, 6, 16)

À primeira vista, tão somente situações ordinárias foram expostas na epístola. Longos banhos e mesa servida com qualidade compunham alguns dos hábitos de Plínio, o Velho, que, ao se dar ouvidos ao som oco do cajado de Esculápio, aventariam para problemas cardíacos e respiratórios animados pela corpulência de Plínio (SERBAT, 2011, p. 39). Livros e mais livros sinalizavam a presença de um erudito. Conta-se, até mesmo, que suas anotações valiam mais de 400 mil sestércios. ${ }^{2}$ Quando, porém, já principiava a noite, a aparição de nuvens disformes anunciava com a força dos inspirados aedos gregos o que era, o que é e o que seria da vida de Plínio. Se ele foi um homem com afeto às letras e ao exercício de cargos públicos romanos; agora era a fagulha de esperança para muitos moradores de Pompeia e, num futuro próximo, seria colocado sob o jugo da gramática própria da natureza que não responde ao léxico e sintaxe dos humanos nem mesmo atende à aritmética estranha dos coveiros.

Perceba que os desmandos naturais perderiam a primazia sob os caminhos da vida de Plínio caso os seus pés tivessem permanecidos descalços e os seus olhos reservados às linhas dos livros que seu sobrinho relatou. Já de pés calçados por suas empoeiradas sandálias, embora sôfrego pela rota desalinhada, os desmandos da natureza se mostraram como algo valioso e muito belo, bem que fatal. De tal modo que, de pés descalços, Plínio lia, escrevia e aprendia, deleitando-se com erudito coração acerca dos gregos Demócrito, Teofrasto e Metrodoro e com os latinos Varrão, Celso, Catão e Cícero. ${ }^{3}$ De pés com sandálias

\footnotetext{
${ }^{2}$ Larcio Licínio, procurador da Hispânia, teria oferecido para Plínio, o Velho, a quantia de 400.000 sestércios por 160 cadernos de anotações (Plin., Epist., 3, 5).

${ }^{3}$ Disse Plínio (Nat. Hist., Praef., 17): "São vinte mil as informações dignas de atenção (porque como disse Domicio Pisão, deve-se construir thesauros oportet e não livros), lidas em cerca de dois mil livros (alguns dos quais poucos estudiosos se deteram devido aos assuntos difíceis de entender), obra de autores bem selecionados, que estão apresentadas em trinta e seis volumes". Dentre estas tantas leituras, todos os nomes citados aparecem como autoridades na elaboração da História Natural.
} 
e certa dose de desassossego, Plínio descobria circunstâncias pasmadas e impetuosas que havia relatado em sua obra História Natural, dedicada ao futuro imperador Tito. ${ }^{4}$

Usar ou não usar as sandálias, eis a questão. Será mais nobre em seu espírito sofrer pedras e temores, ou insurgir-se contra um mar de compromissos e colocar-se aquietado em sua mera existência? Questões que remontam às diversas querelas que a tradição ocidental levantou no tocante aos pareceres da vida de Plínio. Aos luzeiros de Atena olhos-de-coruja, a nobre imagem de Plínio foi pretendida como a de um erudito, um compilador, um homem dos estudos e afeito aos livros, exaltando-se as curvas de seus pés descalços. Já pelos olhos de um divino Odisseu, a imagem de Plínio foi versada em bravura, destacando os traços de explorador, de observador do mundo natural e de homem de ação exaltando-se as tiras de suas sandálias. Nenhuma das duas descrições é completa por si mesma. Para que se deem passos acertados na compreensão de quem foi Plínio, é preciso friccionar ambas as imagens como se buscasse aquela dialética que dita a narrativa da vida de Plínio. À partida revela o desfecho. Não há pés descalços sem pés calçados. Também não há pés calçados sem pés descalços. Sem nenhum gracejo, o que digo é semelhante ao que Platão relatou no início de seu diálogo do Fédon (60-b):

[Diz Sócrates] Como parece aparentemente desconcertante, amigos, isso que os homens chamam de prazer! Que maravilhosa relação existe entre a sua natureza e o que se julga ser o seu contrário, a dor! Tanto um como a outra recusam ser simultâneos no homem; mas procure-se um deles e estaremos sujeitos quase sempre a encontrar também o outro, como se fossem uma só cabeça ligada a um corpo duplo!

Ao tentar apreender a imagem de Plínio com sandálias, apanhamos a contragosto a imagem de Plínio sem sandálias. Mas vai, pega a imagem de Plínio sem sandálias e volta, sem perambular. Verás que falhou. Bom, pés nus - homem que medita em letras - e pés calçados - homem do ofício político. Adquire-se, assim, a imagem de um típico homem romano do século l, que se ocupava tanto com as funções públicas imperiais quanto com as incursões no mundo da erudição literária. O próprio Plínio, o Velho, no prefácio de sua História Natural (Praef., 18), revelou como esta dinâmica era possível,

[...] não temos dúvidas de que muitas coisas nos escaparam [assuntos]; pois somos apenas humanos, e cercados de deveres, e levamos a cabo este tipo de interesse [os estudos; escrita da obra] apenas em nossos momentos de folga, ou seja, à noite - para que ninguém dos seus pense que nossas horas da noite são dadas ao nada. Os dias nós devotamos a você, e o nosso sono é visto apenas nos termos de nossa saúde [...] para estar vivo é preciso estar acordado.

\footnotetext{
${ }^{4}$ Disse Plínio (Nat. Hist., Praef., 1): "Estes livros de História Natural, nascidos de minha última criação/juízo e que são uma nova tarefa para as Musas de seus cidadãos romanos, resolvi oferecê-los a ti com esta informal epístola, Gracioso Imperador (tal é, de fato, o título que mais se ajusta à sua pessoa, já que o de Máximo corresponde à velhice de seu pai)".
} 
Primeiro, para os contemporâneos, este trecho é quase um insulto. Durante todo o dia a nau é ordenada pelos embaraçosos compromissos imperiais. Durante parte significativa da noite a mesma nau é aprontada para lançar-se ao imenso mar dos estudos. Todo navegar ciente de seus infortúnios e incompletudes. Já o sono era como um simples passageiro ou fraco remador que atendia apenas ao mero chamado da saúde. Para estar vivo é preciso estar acordado. O sono nada mais é do que os juros cobrados de modo antecipado pela devastadora morte. Ao friccionar dia e noite estudos literários e deveres imperiais desvelam-se as influências avolumadas que ditavam os pensares e fazeres de Plínio, o Velho. ${ }^{5}$

Como algo falso não diria, pois era deveras inteligente, trago outro testemunho de Plínio, o Jovem, sobre seu tio. Esta epístola fora endereçada a Bébio Macrino. Nela, o sobrinho colocou alguns hábitos de seu tio em tempos de bom-convés, ou seja, sem as ondas que rugiam na proa:

[...] quando regressava para casa destinava o tempo restante a seus estudos. Depois de sua refeição (que todos os dias eram simples e leves como mandavam os velhos costumes), frequentemente no verão, se tivesse tempo livre, tomava sol enquanto lia e fazia anotações de algum livro. Fazia isto todos os dias e costumava dizer que não existia um livro tão ruim que não se pudesse aproveitar nenhuma parte. Depois do sol geralmente tomava um banho frio para logo comer e dormir um pouco, depois estudava como se um novo dia tivesse começado, até a hora do jantar, durante o qual também era lido um livro em voz alta, do qual tomava rapidamente algumas notas. [...] em seus aposentos só parava seus estudos no tempo de seu banho, ou melhor, de suas imersões, pois enquanto se secava fazia com que algo fosse lido (Plin., Epist., 3, 5).

Possivelmente, no quanto é possível especular, Aulo Gélio, pensador da segunda metade do século II, influenciado por testemunho tão marcante, assentou Plínio, o Velho, no trono portentoso do "homem mais dotado de talento e prestígio de sua época" (Aulo Gélio, Noctes Atticae, 9, IV, 13-14). Contrariando a Aulo Gélio de modo absoluto, o moderno Arthur Schopenhauer (2007) proferiu as críticas mais mordazes a Plínio, o Velho. Disse que as obras de Plínio seriam meras reproduções de trabalhos que outros escreviam. O resultado de tantas leituras nas horas do banho e das refeições seria a anulação do pensamento próprio e o raiar do afluxo contínuo de pensamentos alheios. ${ }^{6}$

\footnotetext{
${ }^{5}$ No tocante à História Natural a lista das autoridades estrangeiras é composta por 308 nomes. A lista das autoridades latinas também é composta por grande número de autores, 134.

${ }^{6}$ Arthur Schopenhauer (2007) em seu texto Sobre a erudição e os eruditos: "Até mesmo quando se relata, a respeito de Plínio, o Velho, que ele lia sem parar ou mandava que lessem para ele, seja à mesa, em viagens ou no banheiro, sinto a necessidade de me perguntar se o homem tinha tanta falta de pensamentos próprios que era preciso um afluxo contínuo de pensamentos alheios, como é preciso dar a quem sofre de tuberculose um caldo para manter sua vida. $\mathrm{E}$ nem a sua credulidade sem critérios, nem o seu estilo de coletânea, extremamente repugnante, difícil de entender e sem desenvolvimento contribuem para me dar um alto conceito do pensamento próprio desse escritor".
} 
Agora, se acaso fosse possível, ouve-me Schopenhauer (2007). Presumo que o cálice do esquecimento ou da impostura fora bebido por ti e pelos modernos. O relato da epístola mostra um homem em busca da máxima erudição que o ócio produtivo poderia proporcionar. Agora, se acaso fosse possível, ouve ao próprio Plínio, Schopenhauer: "Esta árdua tarefa de dar novidade ao velho, autoridade ao novo, brilho ao antiquado, luz ao escuro, graça ao tedioso, credibilidade ao duvidoso [...]. Por isso, para nós, mesmo que não tenhamos conseguido, és belo e magnífico termos proposto [tal tarefa]" (Plin., Nat. Hist., Praef., 15). Ouvindo a mim ou ao Plínio, é sábio concordar que: digno de um cidadão tipicamente romano do século I, o conhecimento da tradição advindo de insaciáveis leituras ou a partir da oralidade era uma prova do respeito do que viera antes e não de uma inabilidade de pensar.

Falei novamente cidadão tipicamente romano. Quanto a isto, devo algumas palavras dizer. Seja pelas sandálias-literárias, seja pelas sandálias-ofício, Plínio alimentou aquele ânimo expansionista que regia o século I. Uso, então, tipicamente romano como uma expressão que conduz o leitor pelo infinito mar faz-onda que emerge e mergulha as nuances de um cotidiano romano marcado por triunfos. Ser um cidadão tipicamente romano é de imediato vestir-se com o véu da humanitas. Felicitar a grandeza de Roma. Na potente glória pessoal pressentir a suprema glória do Império. Como bem disse Plínio, o Velho (Nat. Hist., Praef., 16), com estranheza à postura de um agigantado romano:

De minha parte, penso que, na composição do saber, é particularmente meritória a causa dos que têm preferido o serviço útil de superar as dificuldades do que apenas buscar aquilo que dá prazer. Tenho praticado tal postura em outros estudos. E por isso declaro que me surpreendo de que Tito Lívio, o célebre autor, em um determinado volume de sua história, que começa da fundação da urbe, tenha começado dizendo que ele havia alcançado muitas glórias e que poderia descansar se a inquietude de seu espírito não se alimentasse de trabalho. Porque deveria ter composto esses escritos para a glória do povo vencedor do mundo e do nome de Roma, não para glória pessoal.

Atenção. Ser um cidadão tipicamente romano do século I. é olhar até mesmo para o seu próprio passado e encontrar problemas que deveriam ser superados. O serviço útil enriquece os feitos memoráveis. A história da urbe é a história do portar virtudes que o ajuíze enquanto um humano não tirânico. Que soe ser o melhor. Um bom humano. Um bom romano.

Isso dito, Plínio a tudo percebeu e reagiu com o discurso. Compôs diversos trabalhos que o conduziram à pertença desta tipicidade romana. Novamente seu sobrinho, de mãos treinadas e memória impetuosa, guardou em uma de suas cartas $(3,5)$ a lista de obras escritas por seu tio. A vastidão de temas abordados nestes trabalhos desvela 
o vertiginoso caminho por ele seguido: Sobre o lançamento de dardos a cavalo; Sobre a vida de Pomponio Secundo; Das guerras com os germanos; Sobre os eruditos; Problemas da língua; Continuação da história da Aufídio Basso; História Natural. Dentre esses aí, graciosa ou desgraçadamente, chegou até aqui, após vagar os campos elísios, tão somente a História Natural. O bom de a História Natural ter chegado até os dias de hoje é a própria assertiva escrita por Plínio, o Velho, "isto foi escrito para as pessoas comuns, a multidão de agricultores e artesãos e, depois deles, para os estudantes [...] [não escrevo] para os muito letrados. Não quero Manio Pérsio de leitor, mas quero Junio Congo" (Plin., Nat. Hist., Praef., 7). Comuns continuam-se.

Com a ajuda das epístolas, de seu sobrinho e dos poucos relatos acerca de si mesmo, o entendimento do cidadão tipicamente romano é completado com os ofícios de Plínio. Movendo-se dentro dos meandros de um ordenamento hierárquico, Plínio iniciou sua carreira na Germânia Inferior e Superior, ocupando diversos cargos de oficial do exército às ordens de Domício Corbulão, Pompônio Paulino, Dúvio Avito e Pompônio Segundo. ${ }^{7}$ Cargos ocupados com confiança, mas sem os brilhos auspiciosos como os de um Trajano. Nada fazendo nem falando de imoderado contra Nero, Plínio retirou-se da vida pública nos tempos em que os conselheiros de imperador eram condenados à morte. Que diga Sêneca.

Sem perder-se a si mesmo, Plínio retornou algum tempo à sua cidade natal de Como para redigir suas obras de gramática e de oratória. Após o ano conturbado que sucedeu a morte de Nero, em 69, e com a ascensão e queda de Galba, Otão e Vitélio, Plínio regressou a Roma. Regresso rápido. Do ano 70 ao ano 75, já se lançou agigantado pela confiança conquistada do novo imperador, Vespasiano, ao vento da Gália Narbonense, da Hispania Terraconense e da Gália Belga. Ocupou o cargo de procurator, que o colocou em contato direto com o serviço administrativo vinculado às finanças. ${ }^{8}$ Mas, depois de ocupar

\footnotetext{
${ }^{7}$ Como afirmei noutro momento: "As idas e vindas entre Germânia Inferior e Superior podem ser divididas em 3 momentos: $1^{\circ}$ ) Germânia Inferior: Plínio esteve no território de Ubii, mais precisamente a leste da foz do rio Reno. Deste período, encontramos, na obra História Natural, algumas descrições sobre as condições terríveis das tribos locais, assim como alguns comentários sobre grandes árvores que cresciam nas margens do rio, causando problemas para as embarcações romanas. Aqui temos a afirmação de que se tratava do período de campanha de Domício Corbulão contra os caúcos no ano 47 - envolveu batalhas navais; $2^{\circ}$ ) Germânia Superior: Plínio comenta sobre os ventos quentes de Aquae Mattiacae sobre o Reno até Moguntiacum e também nos fala sobre os peixes da região. Aqui Plínio esteve entre os anos de 50 e 52 acompanhado de seu amigo Pompônio Segundo; $3^{\circ}$ ) Germânia Inferior: parece ser neste terceiro momento que houve o encontro entre Plínio e o filho do Imperador Vespasiano, o futuro Imperador Tito para quem a História Natural foi dedicada. No Prefácio da obra, Plínio nos dá a pista: 'és um bom companheiro em nossos acampamentos [militares]! (Plin., Praef., 3)'. Aqui, Fergus Millar apresenta um rápido cálculo da faixa etária de Tito (nascido em 30 de dezembro do ano 39) e concordamos que a data mais possível da estada de Plínio e Tito na Germânia Inferior tenha sido entre os anos de 57 e 58 servindo à Duvio Avito" (STADLER, 2015, p. 93-94).

${ }^{8}$ Plínio, o Jovem, expôs sua surpresa e admiração com este mundo de ocupações de seu tio. Ocupações literárias e políticas que the pareciam quase impossíveis de se realizar: "Acaso não te pareces, recordando quanto leu e quanto escreveu [Plínio, o Velho], que não é possível que tenhas desempenhado algum cargo ou mantido amizade com o
} 
todos estes cargos e com tudo se admirar, Plínio encontrou seu lugar em Miseno como comandante de frota naval.

Assim, ele, de pés descalços e de pés calçados, foi abundante em sua vida literária e laboral. Encontrou, propagou e criou novos traços da humanitas romana. Traços que a muitos calaram, já que seu modo de explicitar as glórias romanas não fora pelas histórias de sangue e carnificina, mas pelos louvores de um cotidiano marcado pelos afazeres do cidadão comum e da natureza em sua simplicidade. Natureza, que deixava, recémnascida, toda a afronta humana. Pensando bem, o melhor é dar a palavra a ele mesmo:

[...] a natureza mostra sua bondade em relação a nós [...] quando os ossos insepultos estão molhados com o nosso sangue, e, quando nossa loucura finalmente foi descarregada, ela chama a si mesma como um véu, e esconde até mesmo os crimes mortais (Plin., Nat. Hist., 2, 159).

Agora, então, explicitada a expressão cidadão tipicamente romano, retomo ao que ansiava com a longa citação da jovial epístola pliniana endereçada a Bébio Macrino.

Ao interpretar a força das palavras de Plínio, o Jovem, na citada epístola 3, 5, percebe-se o interesse de tornar a seu tio um modelo ideal de cidadão, que flerta com o inalcançável ou com o quase divino. De pronto, a epístola 3, 5 expressa a sua eloquência a partir do excesso. Excesso de zelo. Excesso de familiaridade. Excesso de admiração. Excesso de interesses. Excesso de reverência que me toma ao mirar. Estando assim, amiúde nos excessos, seria ingenuidade não atentar que, conduzindo a seu tio por aquelas palavras de puro deleite, o jovem sobrinho, instruído pelas lições de Nicetas de Esmirna e Quintiliano, agregava a si mesmo os valores e a aparência oportuna de um erudito. Com distinto quinhão e honraria, embarcou na nau, diria Homero em seu Canto $\mathrm{XI}$, verso 534, da Odisseia. Ao navegar pelas veredas de Roma, o pujante sobrinho colhia as honrarias oriundas dos laços familiares que ele compartilhava com um dos melhores navegantes romanos. Plínio, o Jovem, teria ainda dito a Tácito,

Nada chama mais a minha atenção que o amor e o desejo de transcender; [...] estaria o fato de voltar, vencedor, através dos lábios da humanidade. Oh, sim! Só uma obra histórica pode prometer tal feito, pois a oratória e a poesia concedem pouco alcance [...] impulsiona-me a empreender tal esforço [escrever uma obra de história] o exemplo de minha própria família: meu tio - a quem considero, por adoção, como meu pai - deixou escritas obras históricas e, na verdade, de grande volume (Plin., Epist., 5, 8).

imperador? E, pelo contrário, agora que conheces quanto se consagrou a seus trabalhos e estudos, não te pareces que não escreveu nem leu o suficiente? Suas ocupações oficiais colocaram todos os obstáculos possíveis, e não havia nada, todavia, que sua energia não pudesse superar" (Plin., Epist., 3, 5). 
Ao atentar-se ao gozo familiar, compreende-se melhor as letras maliciosamente cândidas de Plínio, o Jovem, pregando sobre a sua própria educação: "aprendi, além do mais, com os sábios, que não existe maior mérito do que seguir os passos de seus próprios antepassados, sempre que tenham transmitido um caminho reto" (Plin., Epist., 5 , 8). Exemplos de sua própria família. Adoção por parte de Plínio, o Velho. ${ }^{9}$ Educação pautada na tradição. Anseios de transcender pelos lábios da humanidade. Logo, alçava-se à Aurora da história ao lado de seu tio.

De fato, tanto a partir dos relatos da epístola 3, 5 quanto da epístola 5, 8, tem-se uma saudação à retidão de Plínio, o Velho. De imediato, seu sobrinho ofereceu nestas epístolas um cálice de vinho doce com mel que, ao se fazer mais astuta a visão daquele que lê, é só uma questão de tempo para perceber que se está diante da figura de um sábio. Não qualquer sábio. O sábio estoico. Aquele que, enunciando o seu próprio nome, sustenta a reconciliação plena do homem com a natureza. Aquele que, rumo às trevas ou à aurora e ao sol, mostra-se passivo e procura a total conformação diante de fatos que não dependem dele. Nunca o ânimo no peito é persuadido. Nunca a escolha destoa do destino. Mas para a minha proposta aqui exposta, um sábio estoico sempre estaria com sandálias e sem sandálias nesta dialética erótico-obscena. Sem sandálias medita, com sandálias age. Diz-nos Dumont (1968, p. 114): "meditando, compreende as razões da harmonia universal; agindo, concorre para essa harmonia".

Tudo isto que digo acerca do sábio estoico, acha-se alinhado com outro pequeno relato escrito por Plínio, o Jovem, acerca de seu tio:

Para atenuar o temor de Pomponiano [amigo de Plínio, o Velho] com o exemplo de sua própria tranquilidade [Plínio, o Velho] direcionou-se ao banho e, uma vez terminado, sentou-se e comeu alegremente, ou, o que não pressupõe uma grandeza de ânimo menor, fingiu estar alegre (Plin., Epist., 6, 20).

Nos limites desta epístola já se narravam os dias em que a terra se mostrava acinzentada com o sopro portentoso do Vesúvio. Plínio, o Velho, com impiedoso ânimo, comportou-se com vultosa sobriedade diante da catástrofe vesuviana. Novamente o banho surgiu como uma trivialidade. Novamente a alimentação foi um triunfo da felicidade. Até mesmo a disposição de espírito em fingir alegria num momento em que os deuses já eram postos na berlinda do outro lado do golfo. Aqui, como dito anteriormente, se observam traços das filosofias propagadas no mundo romano, em especial o estoicismo.

\footnotetext{
${ }^{9}$ Plínio, o Jovem, fora adotado por seu tio no ano de 79, mesmo ano da erupção do Vesúvio e, por conseguinte, da morte de Plínio, o Velho. Disse noutro momento: "Ao se tornar tutor legitimus de Plínio, o Jovem, seu tio o alçou às grandes redes de clientelismo que dispunha - talvez o nome de Virgilio Rufo fosse o mais marcante da carreira de Plínio, o Jovem, e tal indivíduo estava vinculado às redes clientelares de Plínio, o Velho" (STADLER, 2015, p. 91).
} 
Não quero afirmar com isto que Plínio, o Velho, fora um filósofo estoico romano. No entanto, basta folhear as inúmeras páginas da História Natural, que tal como amplo navio mercante, que cruza o grande abismo, expõe em seu tamanho as marcas profundas de seu pertencimento ao mundo filosófico. Cosmologia, agir humano, riquezas, luxúria, vida, morte. Numa expressão: modo de viver. Penso que os saberes estoicos presentes na epístola 6, 20 de Plínio, o Jovem, são mais bem elucidados com apoio no Encheiridion (16), do ex-escravo estóico Epicteto: ${ }^{10}$

Quando vires alguém aflito, chorando pela ausência do filho ou pela perda de suas coisas, toma cuidado para que a representação de que ele esteja envolto em males externos não te arrebate, mas tem prontamente à mão que não é o acontecimento que o oprime (pois este não oprime outro), mas sim a opinião sobre 'o acontecimento'. No entanto, não hesites em solidarizar-te com ele com tuas palavras e, caso caiba, em lamentar-te junto. Mas toma cuidado para também não gemeres por dentro.

Plínio, avistando a aflição que tomava conta de seu amigo Pomponiano, buscou tranquilizá-lo com outros afazeres. A insensatez destruía. Quieto ou risonho, Plínio estava cônscio de que as coisas externas em nada oprimem o humano. Ainda entre os vivos ficaria. Um simples banho e uma refeição simbolizavam o distanciar-se das opiniões que radiavam acerca do fenômeno natural que Ihes aparecia. Em um só ânimo, com ideia e refletida decisão, julgou necessário solidarizar-se com os temores de Pomponiano, mas a outra ponta desta decisão clareava a responsabilização acerca da própria postura.

Depois do banho e de consumir comida e bebida, então Plínio, junto com seu amigo Pomponio, revelaria outro atributo do estoicismo, a chamada ataraxia. De modo pouco apropriado, eis que ela se apresenta nos dias de hoje como a tranquilidade da alma. Estar educado a tal ponto que os contatos com o mundo externo não sejam suficientes para perturbar o bom andar do caminhante, já que não seriam os acontecimentos os responsáveis pelos problemas do humano, mas as opiniões acerca dos acontecimentos. Com satisfação filosófica, Plínio demonstra, com seus atos, a qualificação da vida em torno da calma e do suave fluxo de vida, graças ao aprimoramento de suas virtudes, além do correto uso da proairesis e suas faculdades. Somente assim poderia banhar-se e mesmo fingir alegria sem gemer por dentro, pois estaria capacitado a julgar ou assentir e também a evitar tudo aquilo que não está no poder do humano (FONTOURA, 2017, p. 129).

\footnotetext{
${ }^{10}$ De acordo com Aldo Dinucci e Alfredo Julien (2014, p. 20): "O termo grego encheiridion se diz do que está à mão, sendo equivalente ao termo latino manualis, "manual" em nossa língua. Significa também "punhal" ou "adaga", equivalente ao latino pugio, arma portátil usada pelos soldados romanos atada à cintura [...]. Assim, o Encheiridion serve não como uma introdução aos que ignoram a filosofia estoica, mas antes àqueles já familiarizados com os princípios do Estoicismo, para que tenham uma síntese que possam sempre levar consigo e utilizar. Tal uso se relaciona à tradição estoica da meditação diária, para o que o Encheiridion serviria de guia e inspiração".
} 
O sábio diante do indiferente não necessita demonstrar preocupação, já que não há nenhuma possibilidade de alterar o fluxo dos acontecimentos. Ciente de que o tudo virará o nada se vive tranquilamente. Vive-se de modo completo. Estar diante do prelúdio final não é nem mais nem menos importante do que qualquer outro momento da vida. Mesmo sem fôlego ou sem voz não se demonstrariam nem remorso nem medo. Todos os homens estariam no mesmo estado a partir de seu último dia de vida em diante, assim como eram antes de seu primeiro dia de vida, e nem corpo nem a mente possuiu qualquer sensação após a morte (Plin., Nat. Hist., 7, 188).

Ora, é preciso sempre relembrar que esta imagem de Plínio, o Velho, como um sábio estoico diante dos dissabores que potencializam a vida vivida, era uma tarefa exercida por seu sobrinho mui astuto. Astúcia que honrou o seu tio com palavras que cruzariam os tempos, sempre seguras. Astúcia de envolver-se com fio purpúreo na roca da história, ao apropriar-se pelo viés intimista de um acontecimento natural-histórico que marcou a Antiguidade. Penso que todas estas astúcias satisfaziam ao sobrinho enquanto tudo isto não envolvia a narrativa da morte de seu tio. No entanto, quando ficou responsável pelas palavras brônzeas que da morte silenciosa falariam, sua astúcia foi outra. Se não se pode vencer a morte cabe àquele que narra uma mui bela função: transformar a morte em glória imperecível, fazer do lote comum a todas as criaturas sujeitas ao traspasso um bem que the seja próprio e cujo brilho seja eternamente seu (VERNANT, 1978, p. 31).

Vindo do pasto no bosque, para beber, pois o ímpeto da morte já lhe tocava, o sobrinho comoveu-se. Então, no juízo e no coração, se proporia, após acompanhar de longe a tragédia vesuviana e a fumaça sufocante, a relatar, à semelhança doutras mortes famosas, o fim de seu próprio tio. Não tenho dúvidas de que o pertencimento a uma mentalidade de oralidade fazia com que Plínio, o Jovem, buscasse ouvir uma voz mortuária. Brado que desde os tempos de Homero (Canto X, 190) assim vociferava: "Ouvi meu discurso, companheiros, mesmo sofrendo. Amigos, não sabemos onde é a treva, onde, a aurora, nem onde o Sol ilumina-mortal vai sob a terra nem onde sobe".

Talvez uma das principais narrativas que chegou ao grupo político e literário romano do século I e que influenciou de maneira marcante a construção das imagens dos sábios estoicos do Império Romano foi o diálogo de Fédon, de Platão. Sem o intento de tudo ordenar acerca deste diálogo, apenas indico que nele é narrada a última conversa de Sócrates com seus discípulos antes de sentenciar-se à morte com um cálice de cicuta. $\mathrm{O}$ trecho selecionado compõe parte da narrativa final do diálogo, justamente no momento 
em que Fédon contava a Equécrates sobre a postura ascética de Sócrates diante de sua própria morte, ${ }^{11}$

\begin{abstract}
Ora, meu bom homem, tu que conheces bem esse procedimento, diz-me: o que devo fazer? [perguntou Sócrates ao homem que ia administrar a cicuta]. Nada, ele disse, a não ser beber o veneno, caminhar até sentires tuas pernas pesadas e, em seguida, deitar. O veneno então produzirá seu efeito. Ao mesmo tempo em que falava ofereceu a taça a Sócrates. Este a tomou de sua mão, e muito suavemente, Equécrates, sem esboçar qualquer temor, qualquer mudança da cor de sua tez ou da expressão de sua fisionomia [...], ergueu a taça aos lábios e, com um ar misto de jovialidade e tranquilidade, sorveu o seu conteúdo totalmente (Plat., Fédon, 117b-c).
\end{abstract}

Sem vociferar nenhuma palavra de ódio ou de descontentamento quanto ao seu destino, Sócrates encerra sua vida da forma como sempre pretendeu vivê-la, instruindose pelo diálogo. Não dominando a linguagem da morte corpórea, solicita auxílio para compreendê-la e atendê-la. Bastava fazer aquilo que tão bem fazia nos espaços públicos ao debater com seus concidadãos acerca das virtudes, dos sapatos, das condenações, das palavras e de tantos outros assuntos. Bastava andar. Provavelmente com seus pés comportados em um par de sandálias tal como os pés de Plínio. O movimento do caminhar se revela como rei sublime e campeão pujante. Sócrates caminha com suas sandálias para tornar-se completo, tornar-se plenamente humano e no gesto simples, morrer. Erguendo a taça parece convidar o ausente vinho a misturar-se de forma cristalina e imaginativa no gole que selou o pacto com Tânato. Tranquilo e sem temor, rendeu-se de corpo inteiro e fitando a Críton disfarçou suas últimas palavras numa dívida adormecida a Asclépio.

Como conversava agora mesmo, não sem razão tal relato platônico fora aqui apontado. Plínio, o Jovem, foi quem, em epístolas, prestou glórias ao tom sublime e elevado dos discursos de Platão - "[sobre o filósofo Eufrates] seus discursos possuem um estilo brilhante, majestoso e elegante, e frequentemente adotam, inclusive, aquele tom elevado e sublime de Platão" (Plin., Epist., 1, 10). O mesmo Jovem contou sobre a morte de seu tio, o Velho. Narrativa que herdou ou se hospedou na linguagem mortuária de Platão. Talvez alguém não se convença, ou soe o brado dos amantes ultrajosos das interpretações únicas. Assim, apresento o relato da morte de Plínio, o Velho, nas justas intenções de seu sobrinho e endereçadas a Tácito:

[...] porque os densos vapores obstruíram sua respiração e fecharam sua garganta, que por natureza era fraca e estreita e se inflamava com facilidade. Quando reapareceu ali a luz do sol (três dias depois) seu corpo foi descoberto íntegro

\footnotetext{
${ }^{11}$ A narrativa expressa dentro do diálogo do Fédon é construída a partir da solicitação de Equécrates: "Estiveste tu mesmo, Fédon, junto de Sócrates no dia em que ele tomou o veneno na prisão, ou ouviste de alguém?" (Plat., Fédon, 57-a)
} 
e ileso, todavia coberto com suas vestes, e refletia antes, a aparência de estar dormindo do que a da morte (Plin., Epist, 6, 16).

Ah sublime estado de espírito! Somente os vapores de um vulcão que rompeu o silêncio e soterrou Herculano e Pompeia. Inalando estes densos vapores, Plínio ofendeu seu fraco corpo, que reagiu com o fechar da glote. Se no terceiro dia ressuscitou dos mortos...não, não proferirei tamanha malícia. Se no terceiro dia o corpo de Plínio, o Velho, estava íntegro e ileso não é preciso ser adivinho para consagrar-Ihe uma morte tranquila e jovial como semelhantemente narrou Platão acerca de Sócrates. Já que a comparação foi exposta, espanto-me com um agravante: Plínio, o Velho, morreu sufocado pelos vapores do Vesúvio com a face alva de um Sócrates que tão somente bebeu um cálice de cicuta. Seria a chamada morte doce, que enchendo os pulmões com os vapores vulcânicos vitimiza o vivente com estupor?

Sobre o tempo que passou entre os vapores inalados e a integridade do corpo morto de Plínio, nem mesmo os deuses conhecem este segredo. Porém, o que se passa entre a narrativa da morte de Sócrates, que é levado a deitar para dormir o sono eterno, e a narrativa do corpo morto de Plínio, que se aparenta mais com o ato de dormir do que com o ato de morrer, eis algo que se celebra a parecença sem o auxílio das divindades.

Quão formosa narrativa, que jubilosamente deita o corpo de um romano com prudência exemplar. Se não fosse o testemunho de outro romano não aparentado de Plínio, o Velho, apesar de vinculado a Plínio, o Jovem, ter-se-ia apenas a narrativa maravilhada de um sobrinho entusiasmado. ${ }^{12}$ Suetônio admitiu uma breve descrição com ares de maior veracidade e menor beleza triunfal sobre a morte de Plínio, o Velho:

[Plínio, o Velho] Perdeu sua vida no desastre da Campania. Estava comandando a frota de Miseno durante a erupção do Vesúvio e investigava o fenômeno que ali ocorria, mas foi incapaz de voltar devido aos fortes ventos. Ele foi sufocado pela poeira e cinzas, embora alguns pensem que foi morto por um escravo, a quem pediu para apressar o seu fim, quando foi dominado pelo intenso calor (Suetônio, De Viris Illustribus; Vita Plinii Secundi).

\footnotetext{
${ }^{12}$ Suetônio pertencia ao círculo clientelar de Plínio, o Jovem. Esta íntima relação pode ser observada em uma epístola pliniana enviada ao imperador Trajano: "[1] Meu senhor, Suetônio Tranquilo é um homem perfeitamente honrado, absolutamente íntegro e extremamente erudito. Depois de seguir com atenção desde há muito tempo sua vida e seus trabalhos literários, o admiti em meu círculo mais estreito de amizades, e comecei a admirá-lo ainda mais nestes últimos tempos, já que agora pude observá-lo mais de perto. [2] Há dois motivos principais para que ele desfrute do privilégio dos três filhos: por um lado, é digno da boa opinião que os amigos possuem dele, e por outro, não foi agraciado com um matrimônio fértil, de tal forma que se vê obrigado a suplicar-te, invocando tua bondade e por meu intermédio, aquilo que a má fortuna lhe negou. [3] Estou cônscio, meu senhor, de quão importante é a graça que solicito, mas a solicito a quem sei, por experiência, que atende com magnanimidade a todos os meus desejos. Além disso, podes deduzir facilmente com que avidez anseio obter tua graça pelo fato de que não te rogaria algo semelhante estando ausente de Roma se não o desejasse de todo coração" (Plin., Epist., X, 86-b).
} 
Plínio pôs em marcha sua frota naval em direção ao fenômeno natural que o sentenciou. Salvos ou perecidos, todos os seus comandados o seguiram. Brilha no relato de Suetônio a figura daquele bravo curioso que investigava tanto os céus quanto os mares com a destreza de um Odisseu. Com um final pouco convencional, é verdade, ao herói grego, já que não se tratou de uma feliz travessia nem de um retorno triunfal a Ítaca. A travessia teve apenas o sentido de ida, pois os fortes ventos artificiosos tocavam firmemente o seu peito e impediram o retorno da embarcação, assim como o impediram de respirar. Até aqui o relato é o mesmo daquele apresentado por Plínio, o Jovem, mas um novo ingrediente fora acrescido nesta história de virtudes complexas.

Imagino que, com a ponta de um punhal, gemendo e suando sob a vida fatigante de um comandante naval, Plínio não hesitou diante dos infortúnios orgulhosos da vida, que o sufocavam com vapores, poeira e cinzas e pôs-se nas mãos de um escravo, a quem pediu para apressar o seu fim, quando fora dominado pelo intenso calor. Com tal decisão tomada, enxuga os olhos que com lágrimas ofendiam o seu rosto e abre-se para o campo da divina natureza. Lágrimas não de tristeza e sim de tamanha responsabilidade diante do que se desvelava. Pertencente aos meandros de um modo de viver estoico, Plínio sabia que a morte não deveria nem ser temida nem ser louvada, já que não se tratava de um encargo do humano. Assim, indiferença é a palavra de ordem no vocabulário mortuário de um estoico ou, caso se queira utilizar, de uma das belas expressões homéricas, "se é morto ou vivo é vão discurso" (Homero, Odisseia, IV, 640). Retomando o seu elogioso sobrinho nesta história de Suetônio, aquele diria que a diferença de seu tio com os outros cidadãos que enfrentaram o sopro vingativo de Vesúvio é a de que os outros cidadãos substituíam temores por outros temores, enquanto seu tio substituía razões por outras razões (Plin., Epist., 6, 16).

Re-retomo a Suetônio. Plínio, o Velho, pôs-se nas mãos potentes de um escravo que o livrou do tumulto da existência. Dia 25 de agosto de 79. Morte. Sábio, discreto e respeitado, Plínio morreu como viveu e foi dono de sua morte como fora dono de sua vida. Seja pelas mãos de um escravo, seja pelo sopro vingativo do Vesúvio, Plínio saiu da vida vivida para entrar na obscenidade da história, que ora prefere vê-lo com seus pés descalços ora prefere vê-lo calçado com suas sandálias. Eu, após lavar e vestir sandálias limpas no corpo de um Plínio histórico, prefiro compreendê-lo neste sacrifício historiográfico que, ruminando juízos desacertados, o contempla caído ao chão com um dos pés calçados e outro descalço. 


\section{Referências}

\section{Documentação textual}

ARRIANO FLÁVIO. O Encheirídion de Epicteto. Tradução de Aldo Dinucci, Alfredo Julien. São Cristóvão: Ed. Universidade Federal de Sergipe, 2012.

AULO GÉLIO. Noches Áticas. Traducción de M. Carmen Barrigón Fuentes y Jesús M. Nieto Ibáñez. Madrid: Akal, 2009.

HOMERO. Odisseia. Tradução de Carlos Alberto Nunes. São Paulo: Hedra, 2011.

PLATÃO. Fédon. Tradução de Carlos Alberto Nunes. Belém: Ed. Universidade Federal do Pará, 2011.

PLINIO EL JOVEN. Epistolario (libros I-X) e Panegírico del emperador Trajano. Madrid: Cátedra, 2007.

PLINY THE ELDER. Natural History. Cambridge: Harvard University Press, 1991. v. 1-10.

SUETONIUS. Lives of the Caesars. Cambridge: Harvard University Press, 1914. v. 3.

\section{Obras de apoio}

DINUCCI, A.; JULIEN, A. Introdução. In: ARRIANO FLÁVIO. Encheirídion de Epicteto. São Paulo; Coimbra: Annablume; Imprensa da Universidade de Coimbra, 2014.

DUMONT, J. P. La philosophie antique. Paris: PUF, 1968.

FONTOURA, F. C. da. A ética do bem viver em Epicteto. Porto Alegre: Fi, 2017.

MÁRQUEZ, D.; SÁNCHEZ, D. Introducción. In: PLINIO EL JOVEN. Epistulae II. Córdoba: Alción, 2005.

SCHOPENHAUER, A. A arte de escrever. Porto Alegre: L\&PM, 2007.

SERBAT, G. Plinio el Viejo. Madrid: Gredos, 2011.

STADLER, T. D. O Império Romano em cartas: glórias romanas em papel e tinta (Plínio, o Jovem e Trajano 98/113 d.C.). Curitiba: Juruá, 2013.

STADLER, T. D. Por uma noção de história em Plínio, o Jovem (séc. I d.C.). Tese (Doutorado em História) - Programa de Pós-Graduação em História da Universidade Federal do Paraná, Curitiba, 2015.

VERNANT, J. P. A bela morte e o cadáver ultrajado. Discurso, n. 9, p. 31-62, 1978. 